\title{
Efficient Exploitation of Multiple Novel Bacteriocins by Combination of Complete Genome and Peptidome
}

\author{
Lanhua Yi, Lingli Luo and Xin Lü* \\ Department of Food Nutrition and Safety, College of Food Science and Engineering, Northwest A\&F University, Yangling, \\ China
}

Backgroud: The growing emergence of antibiotic-resistant pathogens including the most dangerous superbugs requires quick discovery of novel antibiotics/biopreservatives for human health and food safety. Bacteriocins, a subgroup of antimicrobial peptides, have been considered as promising alternatives to antibiotics. Abundant novel bacteriocins are stored in genome sequences of lactic acid bacteria. However, discovery of novel bacteriocins still mainly relies on dubious traditional purification with low efficiency. Moreover, sequence alignment is invalid for novel bacteriocins which have no homology to known bacteriocins in databases. Therefore, an efficient, simple, universal, and time-saving method was needed to discover novel bacteriocins.

OPEN ACCESS

Edited by:

Fliss Ismail,

Laval University, Canada

Reviewed by:

Ulisses Padua Pereira,

Universidade Estadual de Londrina,

Brazil

William Farias Porto Universidade Católica Dom Bosco,

Brazil

*Correspondence:

Xin Lü

xinlu@nwsuaf.edu.cn

Specialty section:

This article was submitted to

Food Microbiology,

a section of the journal

Frontiers in Microbiology

Received: 02 March 2018

Accepted: 25 June 2018

Published: 13 July 2018

Citation:

Yi L, Luo L and LüX (2018) Efficient

Exploitation of Multiple Novel

Bacteriocins by Combination of

Complete Genome and Peptidome.

Front. Microbiol. 9:1567.

doi: 10.3389/fmicb.2018.01567
Methods and Results: Crude bacteriocins from both cell-related and culture supernatant of Lactobacillus crustorum MN047 fermentation were applied to LC-MS/MS for peptidome assay, by which 131 extracellular peptides or proteins were identified in the complete genome sequence of L. crustorum MN047. Further, the genes of suspected bacteriocins were verified by expressed in Escherichia coli BL21 (DE3) pLysS. Thereafter, eight novel bacteriocins and two nonribosomal antimicrobial peptides were identified to be broad-spectrum activity against both Gram-positive and Gram-negative bacteria, including some multidrug-resistant strains. Among them, BM1556 located within predicted bacteriocin gene cluster. The most active bacteriocin BM1122 had low MIC values of $13.7 \mathrm{mg} / \mathrm{L}$ against both Staphylococcus aureus ATCC29213 and E. coli ATCC25922. The BM1122 had bactericidal action mode by biofilm-destruction, pore-formation, and membrane permeability change.

Conclusions: The combination of complete genome and peptidome is a valid approach for quick discovery of novel bacteriocins without/with-low homology to known ones. This method will contribute to deep exploitation of novel bacteriocins in genome of bacteria submitted to GenBank.

Keywords: novel bacteriocins, genome, peptidome, cloning and expression, antibiotic-resistance

\section{INTRODUCTION}

Since the discovery of penicillin in 1929, antibiotics have played an indispensable role in human medicine and food production. Unfortunately, antimicrobial resistance is found in all microorganisms, whether bacteria, fungi, virus or parasites (Sabtu et al., 2015). Moreover, many bacteria are resistant to not only single but multiple antibiotics. In 2014, 480,000 new cases of 
multidrug-resistant tuberculosis (MDR-TB) were estimated by WHO. Among MDR-TB, 9.7\% were extensively drugresistant tuberculosis (XDR-TB), which was identified in 105 countries. Klebsiella pneumoniae resistant to carbapenems, which is usually the last line of available treatment, was reported in all WHO regions (Band et al., 2018). According to "global PPL" published by WHO in 2017, the most important resistant bacteria had resistance to carbapenem, 3rd generation cephalosporin, vancomycin, methicillin, clarithromycin, etc. Antibiotic resistance makes the existing drugs become increasingly ineffective or even invalid. Consequently, many common infections are becoming risky or untreatable, leading to longer illnesses and higher mortality, like returning to the pre-antibiotic era. The Centers for Disease Control and Prevention (CDC) estimated that antimicrobial-resistance had caused at least two million illnesses and 23,000 deaths each year in the United States alone (Leal et al., 2017), leading to health and economic burden up to $\$ 55$ billion directly or indirectly. Undoubtedly, antibiotic resistance has become one of the biggest threats to global health in the twenty-first century (ArangoArgoty et al., 2018). However, the discovery of new antimicrobial drugs lags behind the emergence of superbugs. Recently, bacteriocins have attracted much attention because they are not only used as food preservatives but also looked as promising alternatives to antibiotics (Cotter et al., 2013). Bacteriocins are ribosomally synthesized antimicrobial peptides or proteins produced by bacteria with narrow or broad antibacterial spectrum (Cotter et al., 2005). Many bacteriocins are produced by lactic acid bacteria which are generally recognized as safe (GRAS) (Alvarez-Sieiro et al., 2016).

Although hundreds of bacteriocins have been discovered, only nisin has been widely used as food preservative in more than fifty countries. The limitation of bacteriocins as preservatives and antimicrobials in the market mainly derives from narrow-spectrum inhibitory activity and high cost of their commercial production (Fahim et al., 2016). Thus, exploitation of novel bacteriocins with broad-spectrum activity is vital for the development of antibiotic substitutes. Generally, novel bacteriocins are obtained and characterized through traditional purification process combining with mass spectrum (Stern et al., 2006). Okubo et al. (2012) and Ngoc Hieu et al. (2016) purified the proteins, and then applied them to LC-MS/MS to de novo sequencing. Kuyama et al. (2015) purified a human basic fetoprotein, which was subsequently identified by N/C-terminal sequencing. However, the traditional method is time-consuming, most importantly, the uncertainty of novelty makes the research easy to become meaningless. Further, more than one kind of bacteriocins can be produced by lactic acid bacteria, which adds the difficulty by traditional purification. In addition, processes of traditional purification vary with different samples as the component diversity.

Comparing with traditional purification, bacteriocin gene sequence alignment is much more simple, clear and, convenient (Porto et al., 2017). Moreover, another sequence search way of pattern-matching, such as profile Hidden Markov Models (profile-HMM) and regular expressions (REGEX) (Porto et al., 2017), had higher efficiency and higher precision. Lactic acid bacteria (LAB, e.g., Lactococcus, Enterococcus, Oenococcus, Pediococcus, Streptococcus, Leuconostoc, and Lactobacillus species) are the richest sources for bacteriocin production (Makarova et al., 2006). Many genome data of these LAB were stored in GenBank of NCBI. For example, only for Lactobacillus, complete or draft genome sequences of 173 species were submitted. Bacteriocin-coding genes can be identified according to their identity with known bacteriocins in databases. However, the novel bacteriocins, which are possible promising, will be overlooked by sequence alignment if they are not very similar to known genes (Tatusova et al., 2016). Therefore, an efficient, simple, universal and time-saving method was needed to discover more novel bacteriocins.

In the study of Dong et al. (2014), a LC-MS/MS-based de novo sequencing assisted database search was used to identified phosphopeptides, which simplified the whole analysis. However, the used database gathering abundant species limited specificity and accuracy. In this study, with experimentsbased function confirmation, a combined method of complete genome of bacteriocin-producer itself and peptidome was used to specifically discover novel bacteriocins produced by probiotic L. crustorum MN047. The antimicrobial activities of multiple bacteriocins against pathogens were investigated, including against antibiotic-resistant isolates. Then, action mode of the most activity bacteriocin was preliminarily studied.

\section{MATERIALS AND METHODS}

\section{Function Annotation}

Complete genome of L. crustorum MN047 was sequenced in our previous study (Yi et al., 2017). Function annotation was performed using local alignment with databases of NR (NonRedundant Protein Database), Swiss-Prot, TrEMBL, COG (the Clusters of Orthologous Groups of proteins), KEGG (the Kyoto Encyclopedia of Genes and Genomes), and GO (Gene Ontology). Genes potentially related with bacteriocin were identified using BAGEL4 (http://bagel4.molgenrug.nl/) and antiSMASH (http:// antismash.secondarymetabolites.org) (Liu et al., 2016).

\section{Peptidome}

The L. crustorum MN047 was statically incubated in MRS medium (2 L) at $30^{\circ} \mathrm{C}$ for $60 \mathrm{~h}$, after which cell suspension was divided into two equal parts to prepare crude bacteriocin samples. One was prepared by ammonium sulfate precipitation as previous study (Yi et al., 2016). The other was made by $\mathrm{pH}-$ mediated cell adsorption-desorption method (Yang et al., 1992). For the latter, adsorption and desorption $\mathrm{pH}$ value was 5.85 and 2.10 , respectively. Briefly, cell suspension was heated at $70^{\circ} \mathrm{C}$ for $30 \mathrm{~min}$ to kill cells and inactivate enzymes. Then, $\mathrm{pH}$ of cell suspension was adjusted to 5.85 and slowly stirred at $4{ }^{\circ} \mathrm{C}$ for $120 \mathrm{~min}$. Cells were harvested by centrifugation and washed by citric acid-phosphate buffer ( $\mathrm{pH}$ 5.85) for 3 times. Thereafter, $\mathrm{pH}$ of cell suspension was adjusted to 2.10. Supernatant was obtained by centrifugation and its $\mathrm{pH}$ value was adjusted to 7.0, namely, crude bacteriocin was acquired. 
In order to identify potential bacteriocins produced by L. crustorum MN047, the two samples were respectively applied to LC-MS/MS, a Q Exactive mass spectrometer that was coupled to LC-20AD (Shimadzu, Japan). Samples were pretreated using Amicon Ultra centrifugal Filters (10 K, Millipore, USA). Filtered component was loaded onto a Trap column at $8 \mu \mathrm{L} / \mathrm{min}$, followed by a LP-C18 analytical column ( $180 \mathrm{~mm}$ length $\times$ $76 \mu \mathrm{m}$ i.d., $3 \mu \mathrm{m})$ at $300 \mathrm{~nL} / \mathrm{min}$ under gradient elution. MS and MS/MS data were acquired and switched under DDA (data dependent acquisition) mode. Scan of mass-to-charge ratio was $350-1,800 \mathrm{~m} / \mathrm{z}$ at resolution of 70,000 for MS and HCD (high-energy collisional dissociation) fragmentation was used at resolution of 17,500 for MS/MS. Raw files of MS/MS spectra were applied to Maxquant 1.5.2.8 (Cox and Mann, 2008) and MASCOT 2.2 (Koenig et al., 2008) against database of complete genome sequence of $L$. crustorum MN047, as well as databases of antimicrobial peptide APD3 (Wang et al., 2016) (http:// aps.unmc.edu/AP/) and CAMP (Waghu et al., 2016) (http:// www.camp3.bicnirrh.res.in/). Function annotation of suspicious bacteriocins was conducted by InterPro (http://www.ebi.ac.uk/ interpro/) (Jones et al., 2014).

\section{Heterologous Expression of Bacteriocins}

Escherichia coli expression system was used to obtain each one of suspicious bacteriocins. The pET-30a (Novagen, Germany) and E. coli BL21 (DE3) pLysS (Trans, China) were used as expression vector and expression host, respectively. Genome of L. crustorum MN047 was extracted and used as template to amplify genes of 8 hypothetical bacteriocins with 8 pairs of primers shown in Table 1. All PCR reactions ran for 35 cycles under corresponding annealing temperature of each primer pair and PCR products were purified using Gel Extraction Kit (OMEGA, USA). After which, PCR products were inserted into pET-30a by digested with FlyCut ${ }^{\mathrm{TM}}$ Nde I and FlyCut ${ }^{\mathrm{TM}}$ Hind III and ligated with T4 Ligase (all from Trans, China). Specifically, there were no encoding genes on genome for nonribosomal antimicrobial peptide EP-20 and GP-19, so their encoding genes were directly synthesized (Sangon, China) (Table 1) according to amino acid sequence. These recombinant plasmids with specific bacteriocin gene were separately transformed into E. coli BL21 (DE3) pLysS competent cells by heat shock at $42^{\circ} \mathrm{C}$. The transformants with correct insertion of bacteriocin genes were confirmed by PCR amplification and sequencing.

Escherichia coli BL21(DE3) pLysS carrying recombinant vector was incubated in $100 \mathrm{~mL} \mathrm{LB}$ broth containing kanamycin to an $\mathrm{OD}_{600}$ of 0.6 at $37^{\circ} \mathrm{C}$ (shaking at $150 \mathrm{rpm}$ ), and then induced by isopropyl $\beta$-D-thiogalactoside (IPTG) over night at $25^{\circ} \mathrm{C}$ (shaking at $180 \mathrm{rpm}$ ). Cells were harvested by centrifugation $\left(4,000 \times \mathrm{g}, 4^{\circ} \mathrm{C}, 15 \mathrm{~min}\right)$, washed by PBS $(\mathrm{pH}$ 7.2) for three times, and resuspended in $20 \mathrm{mM}$ Tris- $\mathrm{HCl}(\mathrm{pH}$ 6.68). Cells were repeated 5 freeze-thaw cycles to disrupt cells and heated at $80^{\circ} \mathrm{C}$ to kill cells and inactivate enzymes. The supernatants $(1 \mathrm{~mL})$ were collected by centrifugation $(16,000$ $\times \mathrm{g}, 4^{\circ} \mathrm{C}, 15 \mathrm{~min}$ ) and applied to antimicrobial activity test by agar well diffusion method as previous study (Lü et al., 2014) using S. aureus ATCC29213 as indicator. The concentrations of kanamycin and IPTG of each bacteriocin were optimized until an obvious antibacterial activity was gotten. The same treatment of each bacteriocin transformant without inducement was used as control in antimicrobial activity test. One arbitrary unit (AU) was defined as the reciprocal of the highest dilution of the bacteriocin showing a visible clear zone (Jabrane et al., 2002).

\section{Antimicrobial Spectrum}

Some Gram-positive and Gram-negative foodborne pathogenic bacteria including multidrug-resistant strains (Table 2) were used to investigate the inhibitory spectrum of 8 bacteriocins and 2 nonribosomal antimicrobial peptides. Supernatant of cell disruption was used and antimicrobial activity toward all indicators was measured by the agar well diffusion assay.

\section{Purification of BM1122}

Crude bacteriocin BM1122 was dialyzed in a dialysis tube with MW 8,000. Then, the sample within tube passed through an Amicon Ultra centrifugal Filter $(10 \mathrm{~K})$. The permeate was concentrated and purified on an AKTA system (AKTA Purifier 100, GE, Sweden) equipped with an UV detector and an automatic collector. Sample was loaded on a HiTrap Q FF anionexchange column at $1.5 \mathrm{~mL} / \mathrm{min}$. Citric acid-phosphate buffer ( $\mathrm{pH}$ 6.0) was used as equilibrium buffer. Sample was gradiently eluted with $1 \mathrm{M} \mathrm{NaCl}$ in equilibrium buffer. Then, the active fraction was purified by analytical RP-HPLC (Waters 1525, USA) equipped with an Agilent ZORBAX 300SB-C18 column $(250 \times$ $4.6 \mathrm{~mm}, 5 \mu \mathrm{m})$. The mobile phase $\mathrm{A}\left(80 \% \mathrm{H}_{2} \mathrm{O}, 20 \%\right.$ acetonitrile and $0.05 \%$ TFA) and mobile phase $\mathrm{B}$ (100\% acetonitrile) were used in gradient elution. The purified BM1122 was digested by trypsin $\left(37^{\circ} \mathrm{C}, 16 \mathrm{~h}\right)$, and then desalted by a manual Pierce C18 Tips (USA, Thermo Scientific). Subsequently, the sample was applied to LC-MS/MS as above to identify the BM1122.

\section{MIC Value}

The BM1122 from RP-HPLC was concentrated and applied to measurement of MIC value as described method (Bhattacharyya et al., 2017) in 96 well plate (Costar, Corning, USA). S. aureus ATCC 29213 and E. coli ATCC 25922 were used as indicators. Specifically, indicators were cultured at $37^{\circ} \mathrm{C}$ to log-phase and diluted using fresh LB broth to about $10^{6} \mathrm{CFU} / \mathrm{mL}$. The initial concentration of BM1122 was adjusted to $2 \mathrm{~g} / \mathrm{L}$ using sterile PBS buffer, and then it was double diluted to $2^{-1}, 2^{-2}, 2^{-3}, 2^{-4}, 2^{-5}$, $2^{-6}, 2^{-7}, 2^{-8}, 2^{-9}$, and $2^{-10}$. Ten microliter of each BM1122 dilution and $90 \mu \mathrm{L}$ indicator dilution were mixed in wells, and then incubated at $37^{\circ} \mathrm{C}$ for $24 \mathrm{~h}$. MIC was defined as the lowest concentration at which no growth of indicator was observed. Meanwhile, protein concentration of each diluted bacteriocin was measured again by BCA assay in case of deviations of concentrations during serial dilution and BSA was used as standard.

\section{Time-Kill Curve}

Foodborne pathogen L. monocytogenes CMCC54004 and C. sakazakii ATCC29544 were used as indicators. Indicators were cultured at $37^{\circ} \mathrm{C}$ to logarithmic-phase $\left(10^{6}-10^{8} \mathrm{CFU} / \mathrm{mL}\right)$, and then sample BM1122 was added to a final concentration of $4 \times \mathrm{MIC}$. Indicators were continuously incubated at $37^{\circ} \mathrm{C}$, 
TABLE 1 | Oligonucleotide primers used in PCR amplification and synthesized genes in this study.

\begin{tabular}{|c|c|c|}
\hline Primers & Sequence $\left(5^{\prime} \rightarrow 3^{\prime}\right)$ & Restriction site \\
\hline BM173F & GGGAATTCCATATGTCACAAAATACACATAAAGG & Nde I \\
\hline BM173R & CCCAAGCTITATTAGATTCTTAGTATCACGG & Hind III \\
\hline BM797R & СCCAAGCTTCTATGCACTCATTITCAATAAT & Hind III \\
\hline BM1029F & GGGAATTCCATATGGATAAACCAAATATTGCTGAAAT & Nde I \\
\hline BM1122R & СССАAGCTITATTAACTGAGTCCTTCAAAGCCTTA & Hind III \\
\hline BM1556F & GGGAATTCCATATGAAAAGAATATTGTTAAAGTC & Nde I \\
\hline BM1556R & CCCAAGCTITAATGCCAGCGTTGATCAAT & Hind III \\
\hline BM1829F & GGGAATTCCATATGGCAGAAGTAGATCCATCAAAGAT & Nde I \\
\hline BM1829R & CCCAAGCTITATIITTAAGGTIIITCGACAAAATCACG & Hind III \\
\hline BMP32R & CCCAAGCTTCAAGCGATCATCGCGCCACTACTCGTT & Hind III \\
\hline EP-20 & $\begin{array}{l}\text { GGGAATTCCATATGGAAGGTCCGGTTGGTCTGGCAGA } \\
\text { TCCGGATGGTCCGGCAAGCGCACCGCTGGGTGCACCG } \\
\text { TAAAAGCTTGGG }\end{array}$ & Nde I, Hind III \\
\hline GP-19 & $\begin{array}{l}\text { GGGAATTCCATATGGGTCCGGTTGGTCTGCTGAGCAG } \\
\text { CCCGGGTAGCCTGCCGCCGGTTGGTGGTGCACCGTAA } \\
\text { AAGCTTGGG }\end{array}$ & Nde I, Hind III \\
\hline
\end{tabular}

$F$, forward primer; $R$, reverse primer; the underlined sequence is restriction enzyme site.

and $0.5 \mathrm{~mL}$ bacterial suspensions were taken immediately at appointed times $(0.5,1,1.5$, and $2 \mathrm{~h})$. Cell suspensions were 10-fold serially diluted using sterile PBS buffer ( $\mathrm{pH}$ 7.2). Cells of two appropriate serial dilutions were spread on plates of LB medium with triplicate. Bacterial colonies were counted after cultivation at $37^{\circ} \mathrm{C}$ for $24 \mathrm{~h}$. Indicators without bacteriocin were used as controls.

\section{Scanning Electron Microscope and Transmission Electron Microscope}

Electron microscopes were used to visualize action mode of BM1122. Foodborne pathogen L. monocytogenes CMCC54004 and C. sakazakii ATCC29544 were used as indicators. Exponential-phase indicators were treated by a concentration of $2 \times$ MIC bacteriocin at $37^{\circ} \mathrm{C}$ for 0.5 and $2 \mathrm{~h}$, respectively. After washing, fixation and dehydration as described method (Yi et al., 2016), cells were dried by $\mathrm{CO}_{2}$ and coated with gold. Ultrastructure of indicators was observed using a high resolution Nova NanoSEM 450 scanning electron microscope (SEM) (FEI, USA).

Pretreatment of indicators for transmission electron microscope (TEM) was the same with that for scanning electron microscope. After post-fixed by osmic acid, cells were dehydrated using alcohol and permeated using white resin. Embedding was performed by roasting at $55^{\circ} \mathrm{C}$ for $48 \mathrm{~h}$. Seventy nanometer thin sections were prepared on copper grids and stained with lead citrate and uranyl acetate. Ultrastructure observation was conducted on a Tecnai G2 Spirit Bio-Twin TEM (FEI, USA).

\section{Data Availability}

All sequence data that support the findings of this study have been deposited in GenBank under accession numbers: CP017996 (chromosome), CP017997 (plasmid MN047p1), and CP017998 (plasmid MN047p2).

\section{RESULTS}

\section{Function Annotation}

Lactobacillus crustorum MN047, firstly isolated from koumiss, which could produce at least three bacteriocins in our previous study (Yi et al., 2016). Complete genome sequence was investigated to analyze genes related to antimicrobial activity. There were 2218 protein coding genes after prediction of its complete genome sequence. A total of 2,176 genes were assigned a putative function by elaborate annotation based on local alignment using six databases. A gene cluster of bacteriocin (locus_tag: BI355_1567-BI355_1581) (Figure 1) was identified using secondary metabolite-specific database antiSMASH. Among the 15 putative orfs, homologous proteins of the proteins encoded by orf 6 , orf 9 , and orf 10 were widely found in other bacteriocin biosynthetic gene clusters (Smokvina et al., 2013; Toh et al., 2013). The structure of bacteriocin gene cluster predicted in L. crustorum MN047 was similar to that of multipeptide leaderless bacteriocin family (Ovchinnikov et al., 2016), in which a metal resistance protein gene was included beside bacteriocin export/regulation related genes. Bacteriocin immunity gene was not included in the predicted bacteriocin gene cluster, which was a common feature among 


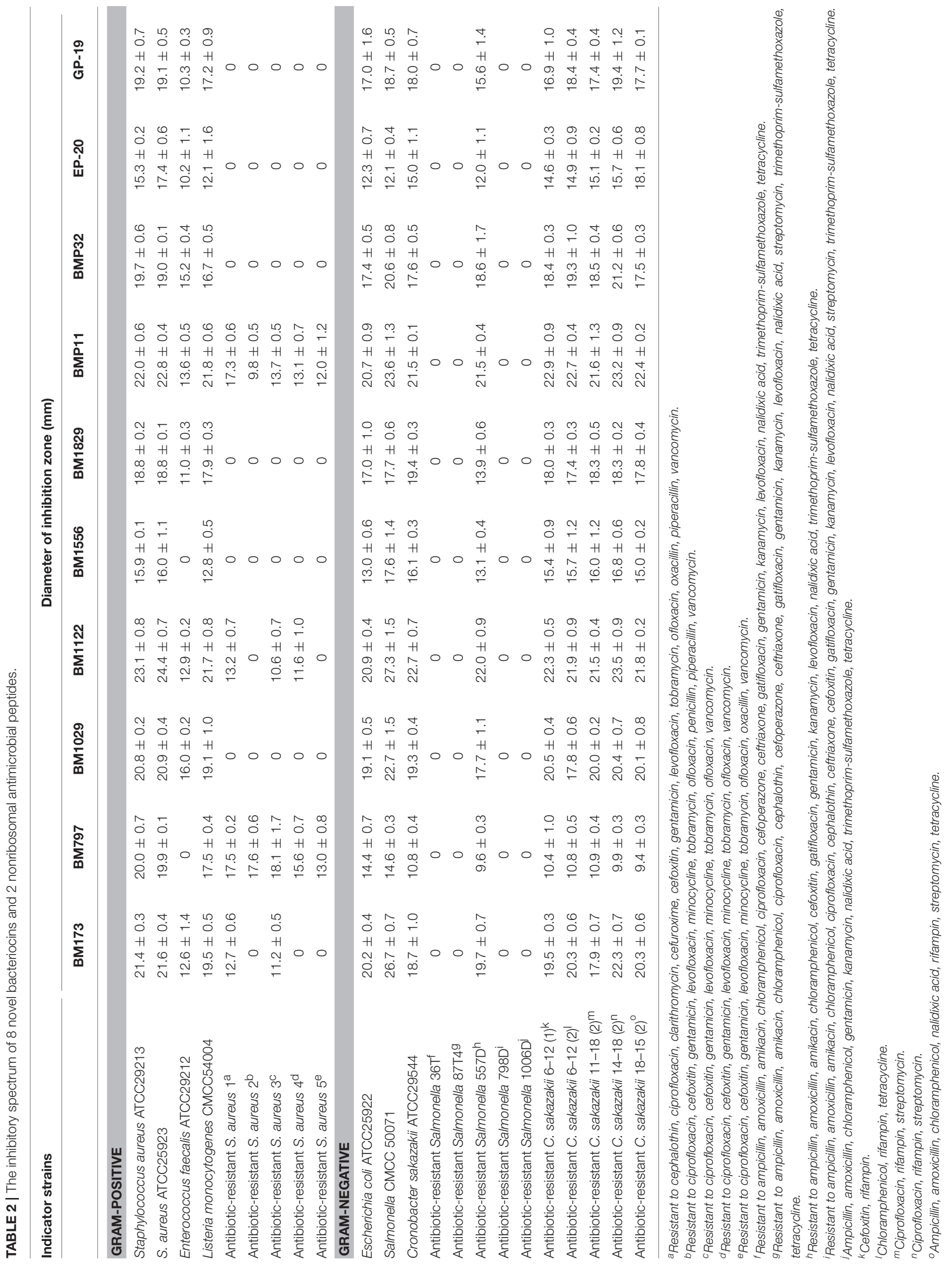




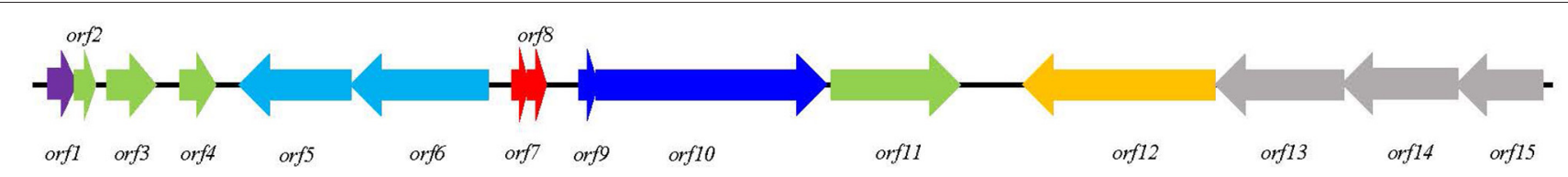

FIGURE 1 | Schematic overview of the bacteriocin gene cluster predicted in L. crustorum MN047 (drawn in scale). Orf1, hypothetical protein (transcriptional regulator, 47\%); orf2, hypothetical protein (IS5/IS1182 family transposase, 94\%); orf3, hypothetical protein (IS5/IS1182 family transposase, 55\%); orf4, hypothetical protein (IS5/IS1182 family transposase, 63\%); orf5, hypothetical protein (ABC transporter permease, 46\%); orf6, bacteriocin ABC transporter ATP-binding protein; orf7, hypothetical protein; orf8, hypothetical protein; orf9, hypothetical protein (bacteriocin ABC transporter, 58\%); orf10, bacteriocin ABC transporter; orf11, IS30 family transposase; orf12, Magnesium transporter; orf13, RluA family pseudouridine synthase; orf14, NAD kinase; orf15, GTP pyrophosphokinase. Putative bacteriocin structure genes (red), ABC transporter genes (blue), transport-related genes (light blue), regulatory related genes (green), transcriptional regulator (purple), metal resistance gene (orange), and other genes (gray).

TABLE 3 | Information statistics of targeted suspicious bacteriocins.

\begin{tabular}{|c|c|c|c|}
\hline NO. & Name ${ }^{a}$ & Sequences & Function annotation ${ }^{b}$ \\
\hline 1 & BM173 & MSQNTHKGMTGHRRPVNQKNGAEKRAKTQAVLDFLRSRDTKESK & hypothetical protein \\
\hline 2 & BM797 & MRYKVTLDTKQQLFTVFDKKNTRVSACGKSIEEAMNKLLKMSA & hypothetical protein \\
\hline 3 & BM1029 & $\begin{array}{l}\text { MDKPNIAEMIIQYEKNKDMTDTQFAFESHLSVERVHNLKSGDYEPTA } \\
\text { DEIKTVQEYIKLHQ }\end{array}$ & $\begin{array}{l}\text { putative } \lambda \text { repressor-like DNA-binding } \\
\text { protein }\end{array}$ \\
\hline 4 & BM1122 & $\begin{array}{l}\text { MANKAELIDSVASKTGLTKKDATSAVDAVFETIQENLSEGNKVQLIGFGN } \\
\text { FEVRQRAARKGRNPQTGEEIKIPASKVPAFKPGKALKDSVK }\end{array}$ & DNA-binding protein \\
\hline 5 & BM1556 & MKRILLKSDRTLDDSELAKVIGGGFFEGIGRWIDQRWH & putative bacteriocin \\
\hline 6 & BM1829 & $\begin{array}{l}\text { MAEVDPSKMADAAIAKEPEVLNLKMSEAFDWSDDDTWRDAIWD } \\
\text { YFMENNNHDTVKTEEAEKPFLDMKDEEVRDFVEKNLKK }\end{array}$ & hypothetical protein \\
\hline 7 & BMP11 & MSINKQKISRNKVLNLLTLFQLLISLYQVIKTIKKGK & putative transmembrane protein \\
\hline 8 & BMP32 & $\begin{array}{l}\text { MTVTDPRSPLTTWIFFCSKKTTPPLKGAWMPNSGLSRHLHYLRLSSR } \\
\text { CLSNSRNTPTSSGAMIA }\end{array}$ & hypothetical protein \\
\hline
\end{tabular}

${ }^{a} B M$ is the abbreviation of bacteriocin MNO47.

${ }^{b}$ Predicted by InterPro (http://www.ebi.ac.uk/interpro/).

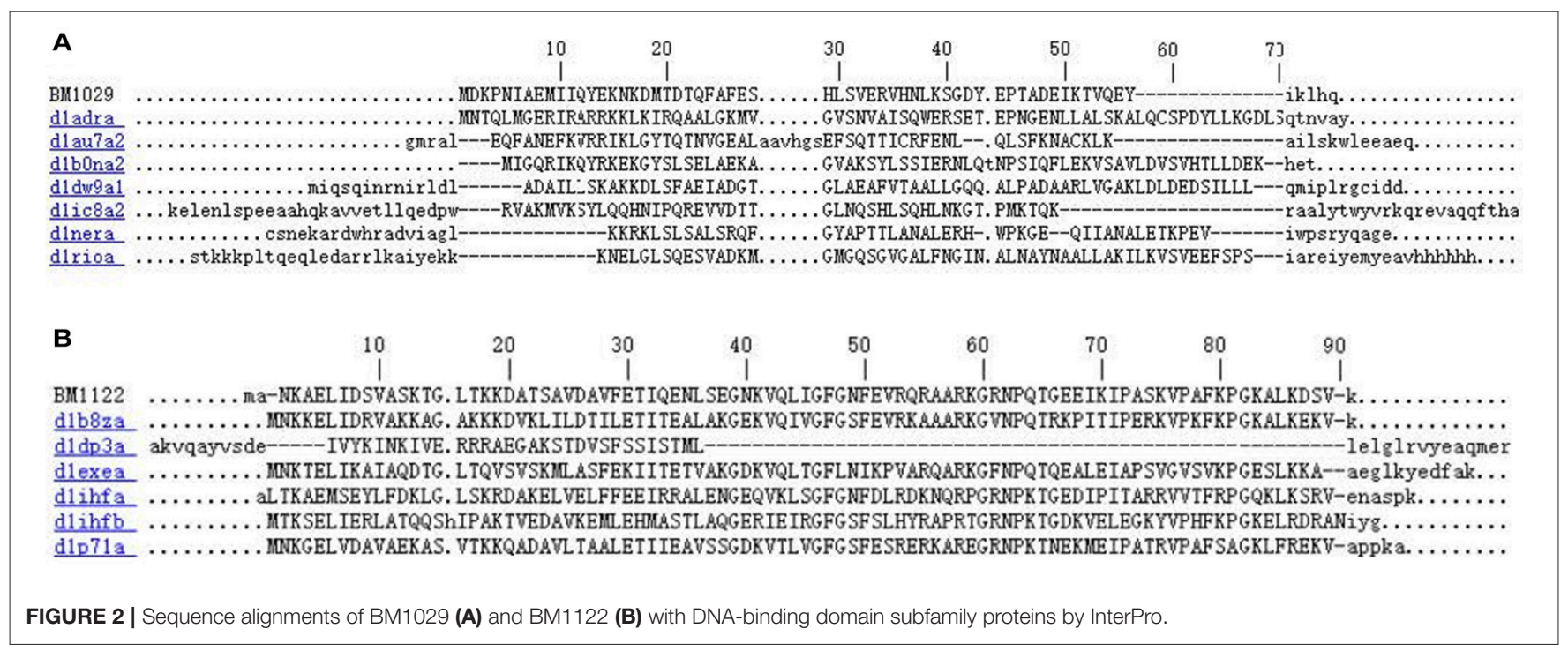

leaderless bacteriocins (Alvarez-Sieiro et al., 2016). One or both proteins from orf 7 and $\operatorname{orf} 8$ were putative bacteriocin structural gene, which should be verified further. Although lack of genes encoding immunity protein in the bacteriocin gene cluster, four genes of bacteriocin immunity protein (locus_tag: BI355_0201,
BI355_0202, BI355_2153, and BI355_2161) were found on chromosome far from the bacteriocin gene cluster. The multiple bacteriocin immunity proteins may be related to the multiple bacteriocins produced by L. crustorum MN047. In addition, a CvpA family protein (colicin V production protein, locus_tag: 

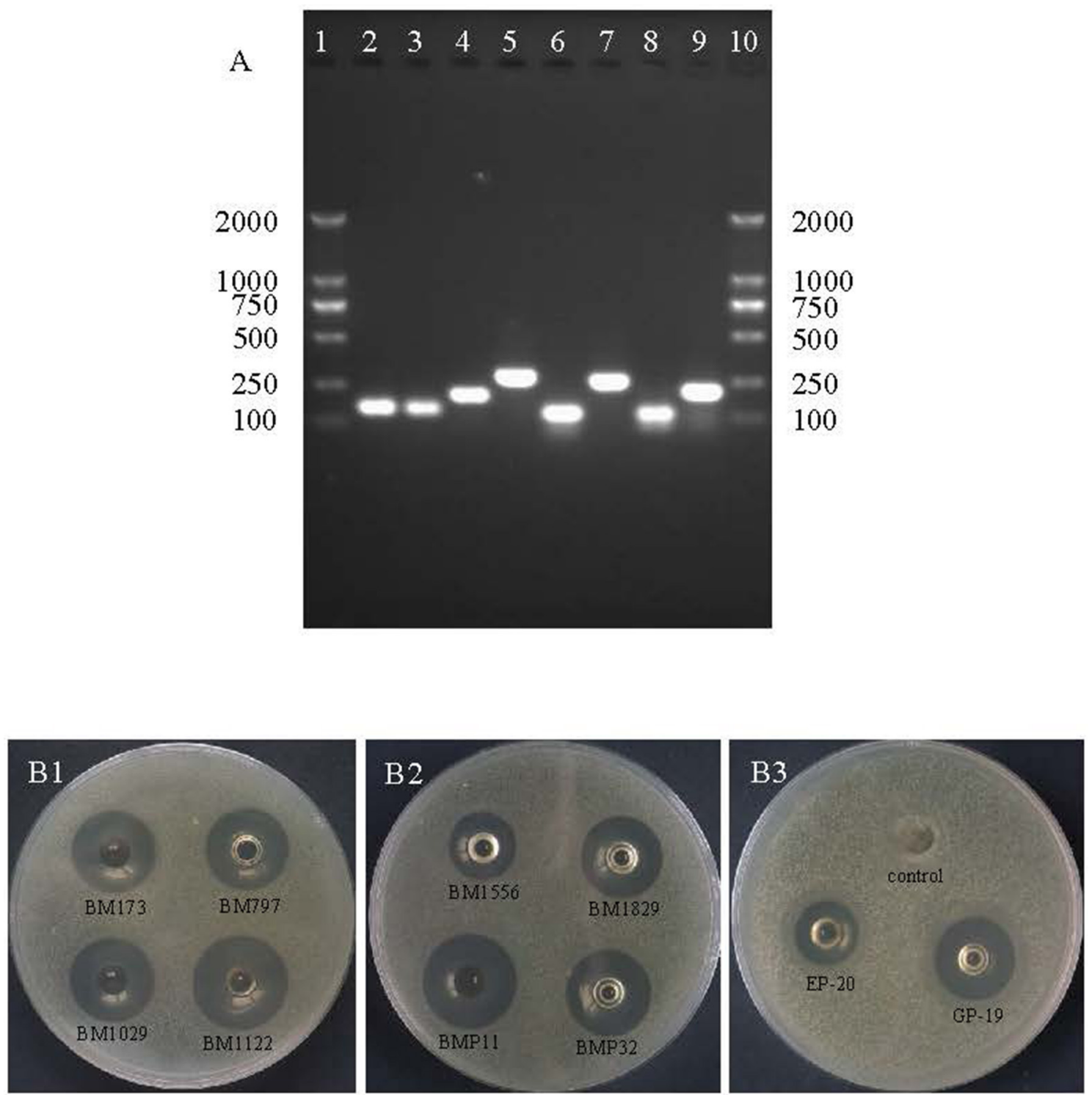

FIGURE 3 | DNA agarose gel electrophoresis of PCR products of 8 hypothetical bacteriocins and inhibition zones against S. aureus ATCC29213. (A) Lane 1 and 10 are DNA marker (Novagen); lane 2 is gene of BM173; lane 3 is gene of BM797; lane 4 is gene of BM1029; lane 5 is gene of BM1122; lane 6 is gene of BM1556; lane 7 is gene of BM1829; lane 8 is gene of BMP11; lane 9 is gene of BMP32. (B1) Inhibition zones of BM173, BM797, BM1029, and BM1122; (B2) inhibition zones of BM1556, BM1829, BMP11, and BMP32; (B3) inhibition zones of EP-20, GP-19 and control without induction.

BI355_0565) was located on chromosome which might involve in bacteriocin biosynthesis.

However, no peptide or protein was annotated to be bacteriocin by database BAGEL3 and antiSMASH that no one had identity more than $50 \%$ with known bacteriocins in databases. Also, no encoding gene of bacteriocin BMA identified in our previous study (Yi et al., 2016) was found. Therefore, the BMA might be a nonribosomal antimicrobial peptide. Bacitracin is a nonribosomally synthesized peptide, two bacitracin export ATP-binding proteins (locus_tag: BI355_1593 and BI355_2140) were located on the chromosome of $L$. crustorum MN047. Moreover, an ABC transporter ATP-binding protein (locus_tag: BI355_1814) and four ABC transporter permeases (locus_tag: BI355_1140, BI355_1815, BI355_1888, and BI355_2139) of ABC-type antimicrobial peptide transport system were contained. They could be responsible for the transportation of nonribosomally synthesized peptides produced by L. crustorum MN047.

\section{LC-MS/MS}

It is an obvious contradiction that multiple bacteriocins were found according to traditional purification process in our previous study while no related genes were annotated in the complete genome. There is only one possible reason that bacteriocins produced by L. crustorum MN047 are novel without any record in databases. Bacteriocins are extracellular 


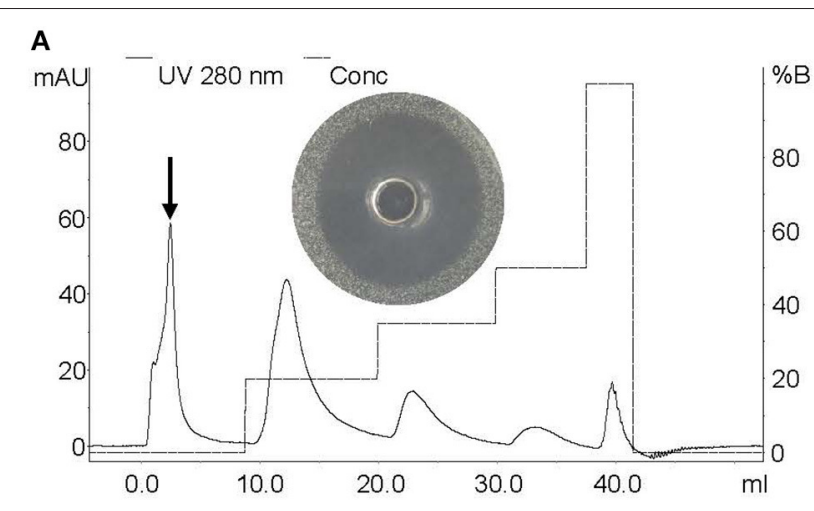

B

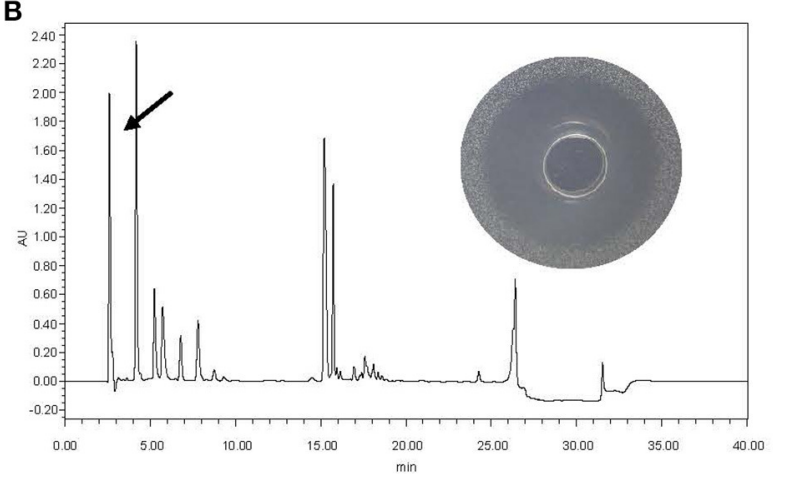

FIGURE 4 | Purification of BM1122 by chromatographic columns. (A) Anion-exchange column and inhibition zone of arrowed peak. (B) RP-HPLC and inhibition zone of arrowed peak. The $y$-axis in (B) is the absorbance value (arbitrary units, AU) under $215 \mathrm{~nm}$. Solid line is $280 \mathrm{~nm}$, dotted line is conc.

antimicrobial peptides or proteins existed in both culture supernatant and cell associated form (Dündar et al., 2015). Ammonium sulfate precipitation can concentrate bacteriocins in culture supernatant. Moreover, $\mathrm{pH}$-mediated cell adsorptiondesorption method is good for cell associated bacteriocins. In this study, two methods above were used simultaneously to prepare crude bacteriocins.

MS/MS data were matched to complete genome sequence of L. crustorum MN047, by which 66 and 170 peptide sequences were identified from ammonium sulfate precipitation sample and pH-mediated cell adsorption-desorption sample, respectively. They were fragments of 131 extracellular peptides or proteins of L. crustorum MN047 on chromosome or plasmid. The identified peptides with molecular mass $<10,000$ and indefinite function annotation were focused. Finally, eight peptides were selected as suspicious bacteriocins (Table 3). Among them, the BM1556 was one of the putative structural genes of bacteriocin gene cluster above. The BM1029 was predicted to be putative $\lambda$ repressorlike DNA-binding protein by InterPro according to structure similarity despite of a low sequence identity (Figure 2A). The BM1122 was annotated to be DNA-binding protein with a high sequence identity (Figure 2B). For the eight peptides, BM797 was from crude bacteriocin of ammonium sulfate precipitation, others were from $\mathrm{pH}$-mediated cell adsorptiondesorption sample. On the other hand, two nonribosomal antimicrobial peptides (EP-20 and GP-19) were also identified from the sample of ammonium sulfate precipitation after sequence alignment search in databases of APD3 and CAMP. The two antimicrobial peptides were previously found in symbiotic bacteria Xenorhabdus budapestensis NMC-10 (Xiao et al., 2012). In this study, a combined method of complete genome and peptidome was used to identify bacteriocins, in which the bacteriocins and nonribosomal antimicrobial peptides were not purified. Namely, the samples used in peptidome analysis also contained a mass of undesirable proteins or peptides from metabolites of L. crustorum MN047 and MRS medium (MRS medium contained peptone, beef extract and yeast extract). Therefore, the native masses of bacteriocins and nonribosomal antimicrobial peptides were not displayable by MS analysis as their very low abundance. All MS/MS data of bacteriocins and nonribosomal antimicrobial peptides were showed in Figure S1.

\section{Heterologous Production and Functional Expression of Bacteriocins}

Non-fusion heterologous expression was used to verify these identified bacteriocin encoding genes. After PCR amplification using genome DNA of L. crustorum MN047 as template, genes of 8 hypothetical bacteriocins were all amplified with single band (Figure 3A). E. coli BL21 (DE3) pLysS was used as expression host to reduce the toxicity of bacteriocins or nonribosomal antimicrobial peptides under background expression.

After optimization of kanamycin and IPTG concentration (Table S1), the production and functional expression of bacteriocins were confirmed by antimicrobial activity test using agar well diffusion method. Consequently, the 8 hypothetical bacteriocins and 2 nonribosomal antimicrobial peptides all showed antimicrobial activity compared with control as shown in Figure 3B. The nonribosomal antimicrobial peptide EP-20 had the weakest antibacterial activity (320 $\mathrm{AU} / \mathrm{mL}$ ), the activity of bacteriocin BM797, BM1556, BM1829, and the other nonribosomal antimicrobial peptide GP-19 was 2-fold higher. Other bacteriocins BM173, BM1029, BM1122, BMP11, and BMP32 were 4-fold higher.

\section{Antimicrobial Spectrum}

Antimicrobial spectrum of 8 bacteriocins and 2 nonribosomal antimicrobial peptides was measured as shown in Table 2. All of which had broad-spectrum antimicrobial activity against both Gram-positive and Gram-negative bacteria. These peptides had no remarkable preference between Gram-positive and Gramnegative wild bacteria except for BM797 that the BM797 seemed to be more effective toward Gram-positive strains. The approximate order of inhibitory competence was BM1122 $>$ BMP11 > BM173 > BM1029>BM797> BMP32 > GP-19 > BM1829 > BM1556 > EP-20. Moreover, they also showed antibacterial activity against multidrug-resistant strains. Strains of multidrug-resistant $S$. aureus used in this study were formidable with resistance to different kinds of antibiotics containing multiple lethal modes. The BM797 was specifically more powerful toward multidrug-resistant $S$. aureus than other bacteriocins. The 8 bacteriocins and 2 nonribosomal antimicrobial peptides revealed same antibacterial activity 


\section{MANKAELIDSVASKTGLTKKDATSAVDAVFETIQENLSEGNKVQLIGFGNFEVRQRAARKGRNPQTGEEIKIPASKVPAFKPGKALKDSVK \\ ANKAELIDSVASK DATSAVDAVFETIQENLSEGNK AELIDSVASK \\ KGRNPQTGEEIK VPAFKPGK
GRNPQTGEEIK
GRNPQTGEEIKIPASK
NPQTGEEIKIPASK}

IPASK VPAFKPGKALKDSVK

FIGURE 5 | Covered residues of BM1122 by LC-MS/MS (highlight in yellow). * is the digestion sites of trypsin.

against strains of standard and resistant Cronobacter sakazakii. Among these bacteriocins and nonribosomal antimicrobial peptides, BM1122 exhibited superior activity, which was further studied.

\section{Purification of BM1122}

Crude BM1122 was firstly dialyzed, after which the sample was purified by an anion-exchange column as shown in Figure 4A. Five isolated peaks were obtained for BM1122 and the active peak (arrow in Figure 4A) was collected and applied to RPHPLC. Subsequently, nine clear peaks were gotten (Figure 4B). The summit of active peak (arrow in Figure 4B) was collected. BM1122 was digested by trypsin which acted on arginine (R) or lysine (K). After analysis by LC-MS/MS, 9 fragments of BM1122 (Figure S2) were identified with a coverage of $73.63 \%$. Sequences of both ends and middle were covered (Figure 5), which indicated that the active BM1122 was the core bacteriocin without any remove of N/C-terminal. The unidentified fragments of TGLTK and VQLIGFGNFEVR might attribute to loss during filtration and elution using manual C18 Tips to desalt after digestion.

\section{MIC Value}

Staphylococcus aureus ATCC 29213 and E. coli ATCC 25922, a representative of Gram-positive and Gram-negative bacteria, respectively, were used as indicators. As a result, the MIC value of BM1122 against both indicators was $13.7 \mathrm{mg} / \mathrm{L}$.

\section{Action Modes of BM1122}

Foodborne pathogen L. monocytogenes CMCC54004 and C. sakazakii ATCC29544 were used as indicators to investigate action mode of BM1122. Treatment with BM1122 for $1 \mathrm{~h}$ resulted in $2.9 \log _{10}$ and $3.16 \log _{10}$ reduction for L. monocytogenes and C. sakazakii (Figure 6), respectively. Viable cells further decreased with time, then all treatment caused more than 3 $\log _{10}(99.9 \%)$ reduction. Therefore, bacteriocin BM1122 was bactericidal (Kalia et al., 2009) at concentration of $4 \times$ MIC.

Scanning electron microscope (SEM) and TEM visualized changes of ultrastructure treated by bacteriocin. $L$. monocytogenes (Figure 7A0) and C. sakazakii (Figure 7B0) without treatment showed plump cell profiles with integrated biofilm in SEM. By TEM, cytoplasmic substances of both untreated indicators uniformly distributed (Figures 8A0, B0). However, after treated by bacteriocin, great changes of ultrastructure for both indicators have taken place. For

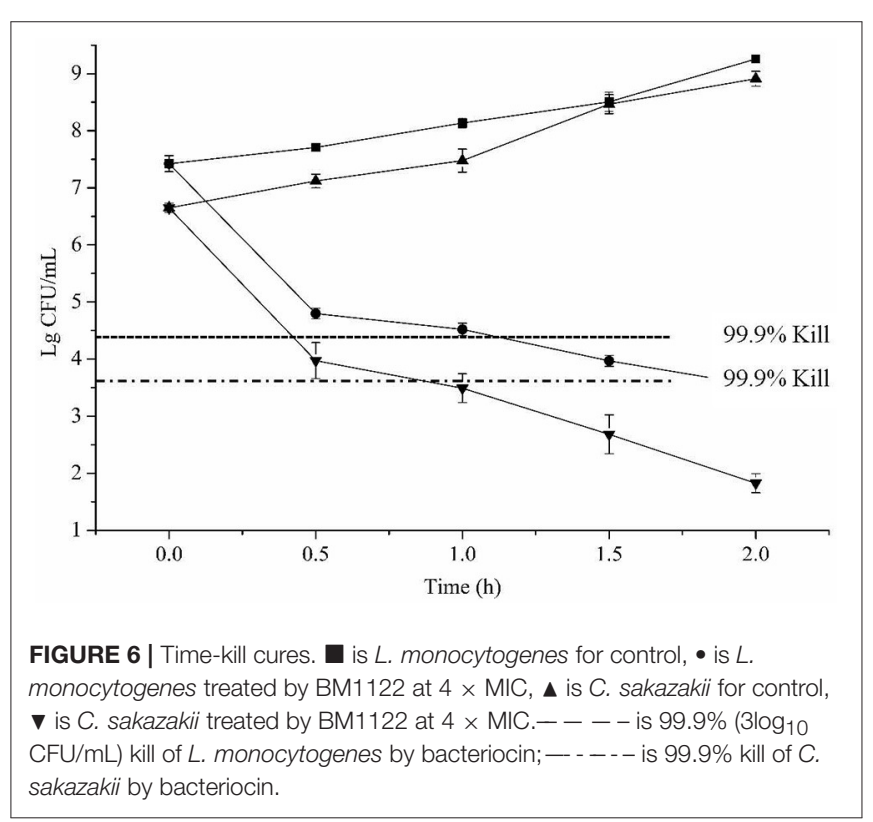

L. monocytogenes, treatment by bacteriocin BM1122 for $0.5 \mathrm{~h}$ caused distorted profiles, biofilm-destruction, and poreformation (Figure 7A1). Prolonged exposure time deteriorated cellular damage, the deformation was aggravated and pores became holes (Figure 7A2). Deformation may be a result of cytoplasm concentrated around cytomembrane and rarefied in the center (Figure 8A1). The nonuniform distribution of cytoplasm substance intensified at $2 \mathrm{~h}$ (Figure 8A2). The falling biofilm dispersed beside cells (arrows in Figures 8A1, A2). The appearance of $C$. sakazakii by BM1122 was different from L. monocytogenes. More pores were formed, as well as deformation was milder (Figure 7B1). The number and size of pores increased with treatment time (Figure 7B2). The abundant pores could pave more passages for outflow of cytoplasmic substances. So, the attenuated cytoplasm was more uniform (Figure 8B1). With longer treatment time, cell envelope was broken and cytoplasm substance was observed outside cells (arrows in Figure 8B2). In addition, BM1122 had very high sequence identity with DNA-binding proteins and conserved structure of histone-like DNA-binding protein. Antimicrobial peptide APP has been reported to have inhibitory activity due to efficient cell-penetrating efficiency, significant physiological 

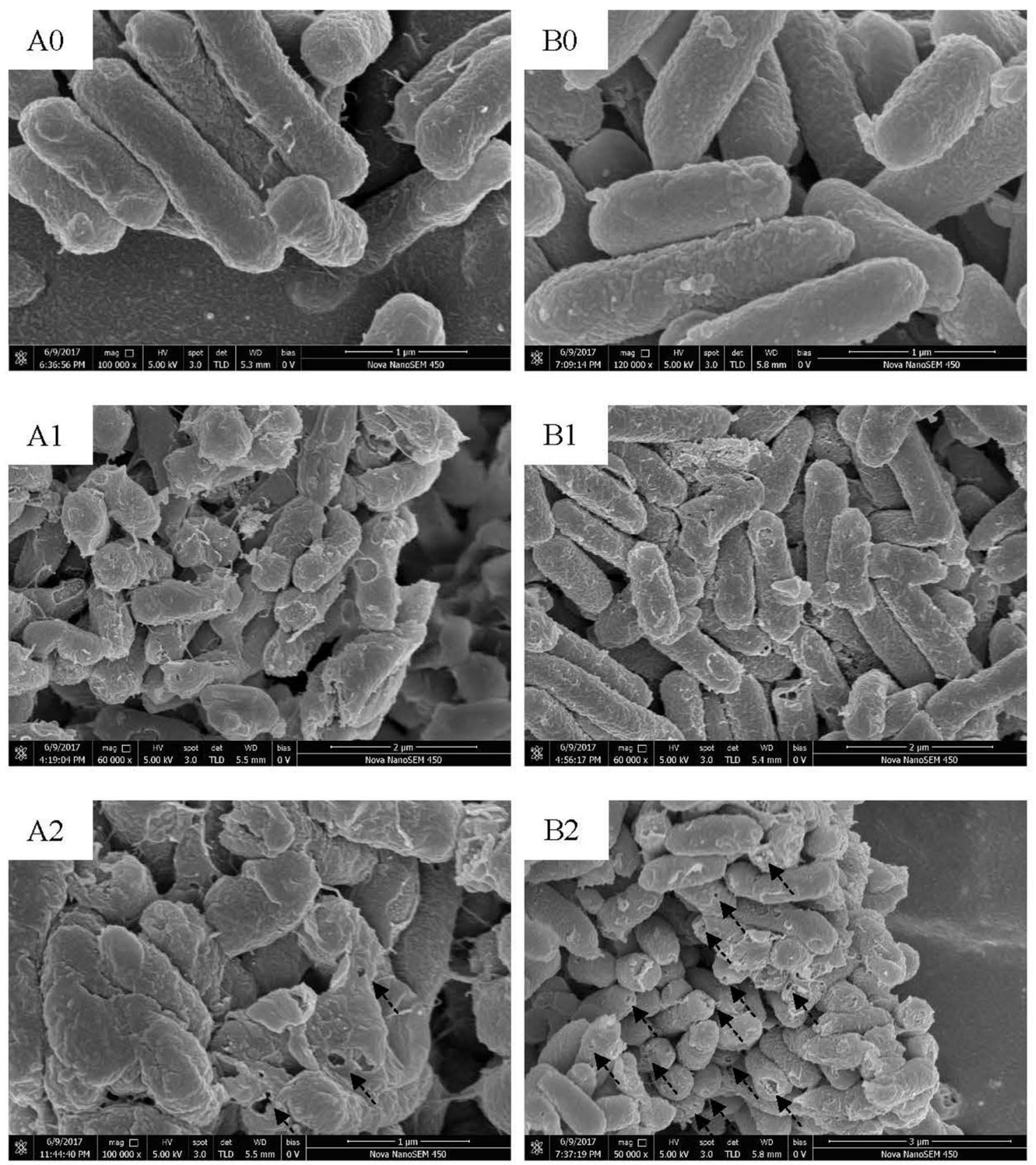

FIGURE 7 | SEM images of L. monocytogenes [control (A0); treated by BM1122 for $0.5 \mathrm{~h}$ (A1); treated by BM1122 for $2 \mathrm{~h}$ (A2)] and C. sakazakii [control (B0); treated by BM1122 for 0.5 h (B1); treated by BM1122 for $2 \mathrm{~h}$ (B2)].

changes and strong DNA-binding affinity (Li et al., 2016). Antimicrobial activity of BM1122 may also partly derive from DNA-binding action like Antimicrobial peptide APP (Li et al., 2016) and MBP-1 (Sousa et al., 2016), which needs to be further verified.

\section{DISCUSSION}

The L. crustorum MN047 strain, a poorly studied species, was isolated from koumiss. Koumiss is traditional fermented mare's milk and used as functional food for medical purposes (Wang et al., 2008; Vimont et al., 2017). A bacteriocin gene cluster was identified on the chromosome of $L$. crustorum MN047. In addition, multiple bacteriocin immunity proteins dispersed on chromosome far from the bacteriocin gene cluster. Moreover, multiple components of antimicrobial peptide transport system were found for L. crustorum MN047. These indicated that the L. crustorum MN047 might be able to produce multiple bacteriocins or antimicrobial peptides as our previous study on this strain (Yi et al., 2016). However, 

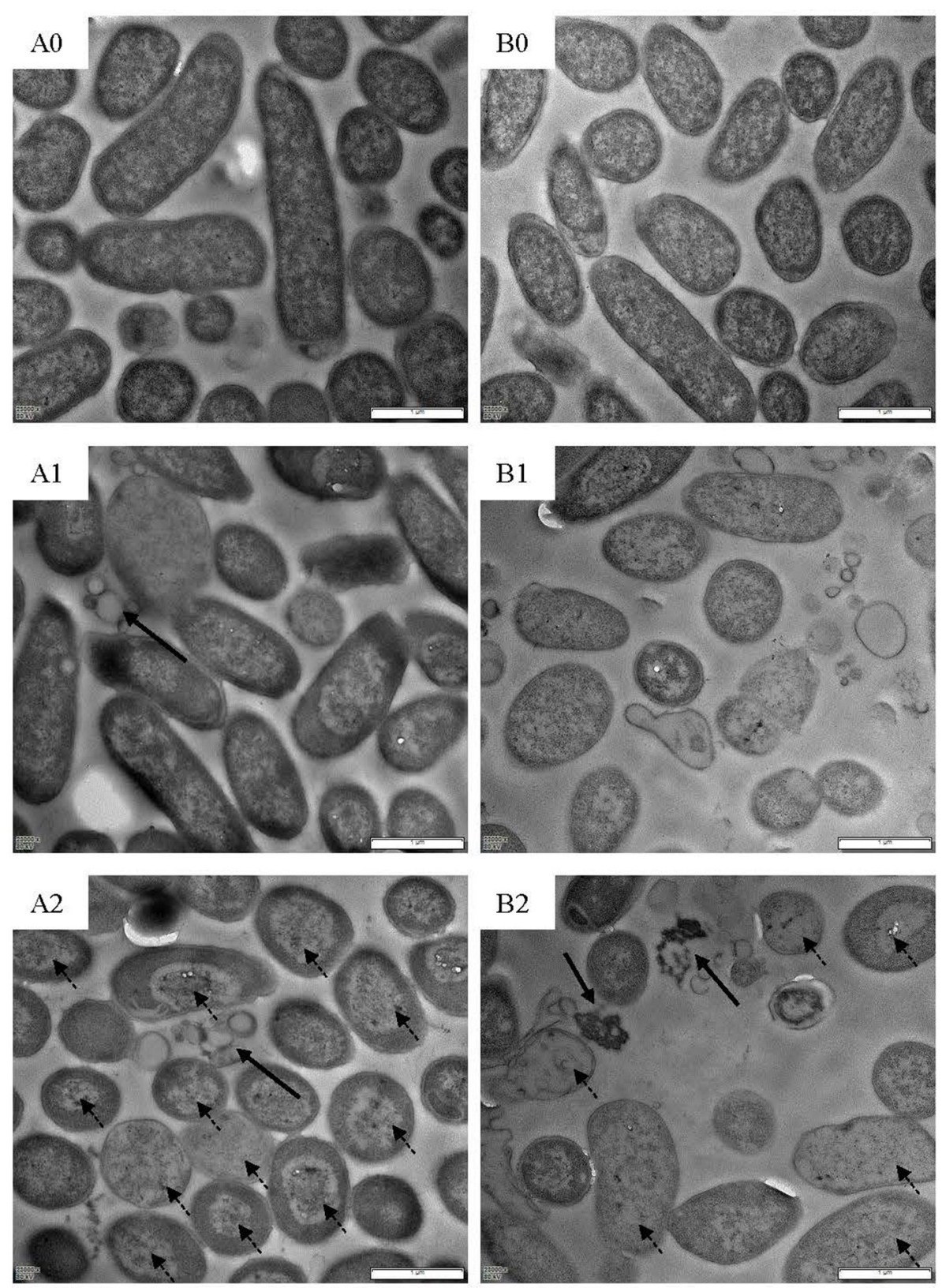

FIGURE 8 | TEM images of L. monocytogenes [control (A0); treated by BM1122 for $0.5 \mathrm{~h}$ (A1); treated by BM1122 for $2 \mathrm{~h}$ (A2)] and C. sakazakii [control (B0); treated by BM1122 for $0.5 \mathrm{~h}$ (B1); treated by BM1122 for $2 \mathrm{~h}$ (B2)].

no exact bacteriocin encoding genes were found after identification in databases of BAGEL3 and antiSMASH. Therefore, bacteriocins produced by the L. crustorum MN047 were novel. After further investigation by combining complete genome and peptidome information, encouragingly eight novel bacteriocins produced by $L$. crustorum MN047 were identified. The function of eight novel bacteriocins was verified by cloning and heterologous expression. It proved that LC-MS/MS-based peptidome analysis combining complete genome is an efficient way to discover new bacteriocins.
Among the 8 novel bacteriocins, the BM1122 was originally annotated as "DNA-binding protein" in the NR database. The remarkable activity as bacteriocin in this study renovated its function annotation. The BM1029 had $\lambda$ repressorlikeDNA-binding domains and the BMP11 had transmembrane region by InterPro analysis. The BM1556 was one of the putative bacteriocin structural genes in bacteriocin gene cluster. The other 4 novel bacteriocins were all originally annotated as "hypothetical protein." Therefore, it is the first time to give a definite functional illustration for them. Biosynthesis mechanisms of other 7 bacteriocins in L. crustorum MN047 were mysterious. These 


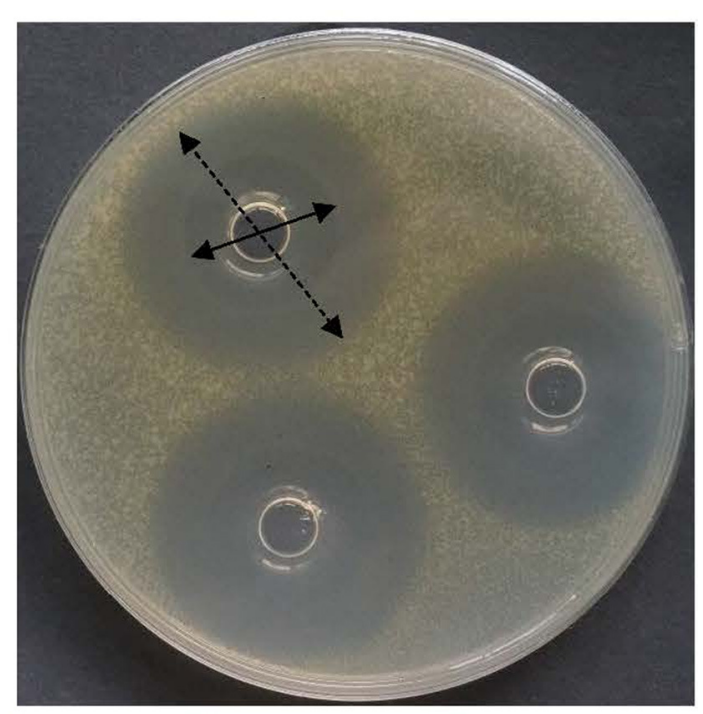

FIGURE 9 | Inhibitory zone of bacteriocin BM1122 against antibiotic-resistant Sakazakii. Solid arrow is totally killed by the bacteriocin, dotted arrow is partially killed by the bacteriocin.

bacteriocins might share the gene cluster of BM1556 because the core genes of biosynthesis and transport were flanked by four insertion sequence (IS) elements (Quintiliani and Courvalin, 1996). This composite transposon was mobile genetic element, which would facilitate the intracellular movement of carried genes (Hochhut et al., 2001). Namely, the composite transposon could play a key role in regulating multiple bacteriocins biosynthesis. As broad-spectrum antimicrobial activity, although these peptides were expressed in E. coli, the self-toxicity had prevented the production of bacteriocin beyond a limit.

Nisin is the only widely used bacteriocin as biopreservative. However, it has a weakness of feeble activity to Gram-negative bacteria. Because of drug efflux pump mechanism of Gramnegative bacteria, it is a common phenomenon for many antimicrobials. Excitingly, the 10 peptides all showed broadspectrum activity against not only Gram-positive but also Gram-negative bacteria. Both Salmonella and C. sakazakii were Gram-negative bacteria, and their multidrug-resistant strains were studied in this work. As shown in Figure 9, an obvious partial killing zone (dotted arrow) was found for Gram-negative pathogens. All data used in this study were total killing zone (solid arrow in Figure 9). Except for antibiotic-resistant Salmonella 557D, other resistant Salmonella strains were all resistant to the ten peptides. However, the resistance-spectrum of 557D contained all detected resistance-spectrum of 1006D. Sensitivity of multidrug-resistant C. sakazakii strains to the ten peptides was the same as that of wild strain. These indicate that antimicrobial mechanism of these peptides may be different from these prevalent antibiotics used in this study.

According to the study of Xiao et al. (2012), the $\mathrm{EC}_{50}$ value of EP-20 to Phytophthora capsici was $3.14 \mathrm{mg} / \mathrm{L}$, that of GP-19 against Verticillium dahlia was $17.54 \mathrm{mg} / \mathrm{L}$. EP-20 was antifungal with weak antibacterial activity while GP-19 had anti-Grampositive, anti-Gram-negative and antifungal activity (Xiao et al., 2012). It is in accordance with the order of inhibitory competence in this study. However, the inhibitory activity of EP-20 and GP-19 was far less than that of BM1122.

The bacteriocin BM1122 had bactericidal action mode, which was powerful in controlling foodborne pathogens. The source of probiotic lactic acid bacteria and proteinaceous nature of BM1122 endow the potential as food preservative. According to SEM and TEM, action mechanisms of BM1122 against Gram-positive and Gram-negative bacteria were different. Action mechanisms of bacteriocins include cell envelope-associated mechanisms (e.g., pore formation, targeting lipid II) and intracellular mechanisms (interfering with DNA, RNA, and protein metabolism) (Cotter et al., 2013). The transmembrane region of BMP11 (Table 3 ) analyzed by InterPro may contribute to its antibacterial activity. For intracellular mechanism, DNA binding also is one approach, such as BM1029 and BM1122 analyzed by InterPro. How much contribution of the DNA binding of BM1029 and BM1122 to antibacterial activity needs to be verified in future study. However, the BM1122 also induced pore-formation (dotted arrows in Figure 7) and permeabilization of membrane according to thinned cytoplasm substance (dotted arrows in Figure 8). The pore-formation and membrane permeabilization could not be the results of DNA-binding. The difference and diversity of action mode contribute to antibacterial activity against broad pathogens, especially antibiotic-resistant strains.

In conclusion, combination of complete genome and peptidome was an excellent method in discovery of novel bacteriocins which were overlooked by general genome annotation. By which, eight novel bacteriocins and two antimicrobial peptides were identified from probiotic $L$. crustorum MN047. It is much more efficient than traditional ways in identification of bacteriocins.

\section{AUTHOR CONTRIBUTIONS}

LY and XL designed the experiments. LY and LL performed the experiments and analyzed the experimental data. LY wrote this paper. All authors read and approved the final manuscript.

\section{ACKNOWLEDGMENTS}

This work was financially supported by Special Fund for Agroscientific Research in the Public Interest of China (Grant No. 201503135). The authors thank Dr. Xin Wang and Dr. Baowei Yang for their kind donation of the foodborne antibiotic-resistant pathogenic strains.

\section{SUPPLEMENTARY MATERIAL}

The Supplementary Material for this article can be found online at: https://www.frontiersin.org/articles/10.3389/fmicb. 2018.01567/full\#supplementary-material 


\section{REFERENCES}

Alvarez-Sieiro, P., Montalban-Lopez, M., Mu, D., and Kuipers, O. P. (2016). Bacteriocins of lactic acid bacteria: extending the family. Appl. Microbiol. Biotechnol. 100, 2939-2951. doi: 10.1007/s00253-016-7343-9

Arango-Argoty, G., Garner, E., Prudent, A., Heath, L. S., Vikesland, P., and Zhang, L. Q. (2018). DeepARG: a deep learning approach for predicting antibiotic resistance genes from metagenomic data. Microbiome 6:23 doi: 10.1186/s40168-018-0401-z

Band, V. I., Satola, S. W., Burd, E. M., Farley, M. M., Jacob, J. T., and Weiss, D. S. (2018). Carbapenem-resistant Klebsiella pneumoniae exhibiting clinically undetected colistin heteroresistance leads to treatment failure in a murine model of infection. Mbio 9:e02448-17. doi: 10.1128/mBio.02448-17

Bhattacharyya, T., Sharma, A., Akhter, J., and Pathania, R. (2017). The small molecule IITR08027 restores the antibacterial activity of fluoroquinolones against multidrug-resistant Acinetobacter baumannii by efflux inhibition. Int. J. Antimicrob. Agents. 50, 219-226. doi: 10.1016/j.ijantimicag.2017.03.005

Cotter, P. D., Hill, C., and Ross, R. P. (2005). Bacteriocins: developing innate immunity for food. Nat. Rev. Microbiol. 3, 777-788. doi: 10.1038/nrmicro1273

Cotter, P. D., Ross, R. P., and Hill, C. (2013). Bacteriocins - a viable alternative to antibiotics? Nat. Rev. Microbiol. 11, 95-105. doi: 10.1038/nrmicro2937

Cox, J., and Mann, M. (2008). MaxQuant enables high peptide identification rates, individualized p.p.b.-range mass accuracies and proteome-wide protein quantification. Nat. Biotechnol. 26, 1367-1372. doi: 10.1038/nbt.1511

Dong, M., Ye, M., Cheng, K., Dong, J., Zhu, J., Qin, H., et al. (2014). Identification of phosphopeptides with unknown cleavage specificity by a de novo sequencing assisted database search strategy. Proteomics 14, 2410-2416. doi: 10.1002/pmic.201400268

Dündar, H., Atakay, M., Celikbicak, O., Salih, B., and Bozoglu, F. (2015). Comparison of two methods for purification of Enterocin B, A bacteriocin produced by Enterococcus faecium W3. Prep. Biochem. Biotechnol. 45, 796-809. doi: $10.1080 / 10826068.2014 .958165$

Fahim, H. A., Khairalla, A. S., and El-Gendy, A. O. (2016). Nanotechnology: a valuable strategy to improve bacteriocin formulations. Front. Microbiol. 7:1385. doi: 10.3389/fmicb.2016.01385

Hochhut, B., Lotf, Y., Mazel, D., Faruque, S. M., Woodgate, R., and Waldor, M. K. (2001). Molecular analysis of antibiotic resistance gene clusters in Vibrio cholerae O139 and O1SXT constins. Antimicrob. Agents Chemother. 45, 2991-3000. doi: 10.1128/AAC.45.11.2991-3000.2001

Jabrane, A., Sabri, A., Compere, P., Jacques, P., Vandenberghe, I., Van Beeumen, J., et al. (2002). Characterization of serracin P, a phage-tail-like bacteriocin, and its activity against Erwinia amylovora, the fire blight pathogen. Appl. Environ. Microbiol. 68, 5704-5710. doi: 10.1128/AEM.68.11.5704-5710.2002

Jones, P., Binns, D., Chang, H.-Y., Fraser, M., Li, W., McAnulla, C., et al. (2014). InterProScan 5: genome-scale protein function classification. Bioinformatics 30, 1236-1240. doi: 10.1093/bioinformatics/btu031

Kalia, V., Miglani, R., Purnapatre, K. P., Mathur, T., Singhal, S., Khan, S., et al. (2009). Mode of action of ranbezolid against Staphylococci and structural modeling studies of its interaction with ribosomes. Antimicrob. Agents Chemother. 53, 1427-1433. doi: 10.1128/AAC.00887-08

Koenig, T., Menze, B. H., Kirchner, M., Monigatti, F., Parker, K. C., Patterson, T., et al. (2008). Robust prediction of the MASCOT score for an improved quality assessment in mass spectrometric proteomics. J. Proteome Res. 7, 3708-3717. doi: $10.1021 /$ pr700859x

Kuyama, H., Yoshizawa, A. C., Nakajima, C., Hosako, M., and Tanaka, K. (2015). Identification of human basic fetoprotein as glucose-6-phosphate isomerase by using $\mathrm{N}$ - and C-terminal sequence tags and terminal tag database. J. Pharm. Biomed. Anal. 112, 116-125. doi: 10.1016/j.jpba.2015. 04.032

Leal, J. R., Conly, J., Henderson, E. A., and Manns, B. J. (2017). How externalities impact an evaluation of strategies to prevent antimicrobial resistance in health care organizations. Antimicrob. Resist. Infect. Control 6:53. doi: 10.1186/s13756-017-0211-2

Li, L. R., Sun, J., Xia, S. F., Tian, X., Cheserek, M. J., and Le, G. W. (2016). Mechanism of antifungal activity of antimicrobial peptide APP, a cellpenetrating peptide derivative, against Candida albicans: intracellular DNA binding and cell cycle arrest. Appl. Microbiol. Biotechnol. 100, 3245-3253. doi: $10.1007 / \mathrm{s} 00253-015-7265-\mathrm{y}$
Liu, H. W., Yin, S. L., An, L. K., Zhang, G. W., Cheng, H. C., Xi, Y. H., et al. (2016). Complete genome sequence of Bacillus subtilis BSD-2, a microbial germicide isolated from cultivated cotton. J. Biotechnol. 230, 26-27. doi: 10.1016/j.jbiotec.2016.05.019

Lü, X., Yi, L., Dang, J., Dang, Y., and Liu, B. (2014). Purification of novel bacteriocin produced by Lactobacillus coryniformis MXJ 32 for inhibiting bacterial foodborne pathogens including antibiotic-resistant microorganisms. Food Control 46, 264-271. doi: 10.1016/j.foodcont.2014.05.028

Makarova, K., Slesarev, A., Wolf, Y., Sorokin, A., Mirkin, B., Koonin, E., et al. (2006). Comparative genomics of the lactic acid bacteria. Proc. Natl. Acad. Sci. U.S.A. 103, 15611-15616. doi: 10.1073/pnas.0607117103

Ngoc Hieu, T., Rahman, M. Z., He, L., Xin, L., Shan, B., and Li, M. (2016). Complete de novo assembly of monoclonal antibody sequences. Sci. Rep. 6:31730. doi: $10.1038 / \mathrm{srep} 31730$

Okubo, B. M., Silva, O. N., Migliolo, L., Gomes, D. G., Porto, W. F., Batista, C. L., et al. (2012). Evaluation of an Antimicrobial L-Amino acid oxidase and peptide derivatives from Bothropoides mattogrosensis pitviper venom. PLoS ONE 7:e33639. doi: 10.1371/journal.pone.0033639

Ovchinnikov, K. V., Chi, H., Mehmeti, I., Holo, H., Nes, I. F., and Diep, D. B. (2016). Novel group of leaderless multipeptide bacteriocins from grampositive bacteria. Appl. Environ. Microbiol. 82, 5216-5224. doi: 10.1128/AEM.0 1094-16

Porto, W. F., Pires, A. S., and Franco, O. L. (2017). Computational tools for exploring sequence databases as a resource for antimicrobial peptides. Biotechnol. Adv. 35, 337-349. doi: 10.1016/j.biotechadv.2017.02.001

Quintiliani, R., and Courvalin, P. (1996). Characterization of Tn1547, a composite transposon flanked by the IS16 and IS256-like elements, that confers vancomycin resistance in Enterococcus faecalis BM4281. Gene 172, 1-8. doi: 10.1016/0378-1119(96)00110-2

Sabtu, N., Enoch, D. A., and Brown, N. M. (2015). Antibiotic resistance: what, why, where, when and how? Br. Med. Bull. 116, 105-113. doi: 10.1093/bmb/ ldv041

Smokvina, T., Wels, M., Polka, J., Chervaux, C., Brisse, S., Boekhorst, J., et al. (2013). Lactobacillus paracasei comparative genomics: towards species pan-genome definition and exploitation of diversity. PLoS ONE 8:e68731. doi: 10.1371/journal.pone.0068731

Sousa, D. A., Porto, W. F., Silva, M. Z., da Silva, T. R., and Franco, O. L. (2016). Influence of cysteine and tryptophan substitution on DNA-binding activity on maize alpha-hairpinin antimicrobial peptide. Molecules 21:E1062. doi: 10.3390/molecules 21081062

Stern, N. J., Svetoch, E. A., Eruslanov, B. V., Perelygin, V. V., Mitsevich, E. V., Mitsevich, I. P., et al. (2006). Isolation of a Lactobacillus salivarius strain and purification of its bacteriocin, which is inhibitory to Campylobacter jejuni in the chicken gastrointestinal system. Antimicrob. Agents Chemother. 50, 3111-3116. doi: 10.1128/AAC.00259-06

Tatusova, T., DiCuccio, M., Badretdin, A., Chetvernin, V., Nawrocki, E. P., Zaslavsky, L., et al. (2016). NCBI prokaryotic genome annotation pipeline. Nucleic Acids Res. 44, 6614-6624. doi: 10.1093/nar/gkw569

Toh, H., Oshima, K., Nakano, A., Takahata, M., Murakami, M., Takaki, T., et al. (2013). Genomic adaptation of the Lactobacillus casei group. PLoS ONE 8:e75073. doi: 10.1371/journal.pone.0075073

Vimont, A., Fernandez, B., Hammami, R., Ababsa, A., Daba, H., and Fliss, I. (2017). Bacteriocin-producing Enterococcus faecium LCW 44: a high potential probiotic candidate from raw camel milk. Front. Microbiol. 8:865. doi: 10.3389/fmicb.2017.00865

Waghu, F. H., Barai, R. S., Gurung, P., and Idicula-Thomas, S. (2016). CAMP(R3): a database on sequences, structures and signatures of antimicrobial peptides. Nucleic Acids Res. 44, D1094-D1097. doi: 10.1093/nar/gkv1051

Wang, G. S., Li, X., and Wang, Z. (2016). APD3: the antimicrobial peptide database as a tool for research and education. Nucleic Acids Res. 44, D1087-D1093. doi: $10.1093 / \mathrm{nar} / \mathrm{gkv} 1278$

Wang, J. G., Chen, X., Liu, W. J., Yang, M., and Zhang, H. P. (2008). Identification of Lactobacillus from koumiss by conventional and molecular methods. Eur. Food Res. Technol. 227, 1555-1561. doi: 10.1007/s00217-008-0880-4

Xiao, Y., Meng, F. L., Qiu, D. W., and Yang, X. F. (2012). Two novel antimicrobial peptides purified from the symbiotic bacteria Xenorhabdus budapestensis NMC-10. Peptides 35, 253-260. doi: 10.1016/j.peptides.2012. 03.027 
Yang, R. G., Johnson, M. C., and Ray, B. (1992). Novel method to extract large amounts of bacteriocins from lactic-acid bacteria. Appl. Environ. Microbiol. 58, 3355-3359.

Yi, L., Dang, Y., Wu, J., Zhang, L., Liu, X., Liu, B., et al. (2016). Purification and characterization of a novel bacteriocin produced by Lactobacillus crustorum MN047 isolated from koumiss from Xinjiang, China. J. Dairy Sci. 99, 7002-7015. doi: 10.3168/jds.2016-11166

Yi, L., Guo, X., Liu, L., Shao, C., and Lu, X. (2017). First report on the complete genome sequence of Lactobacillus crustorum MN047, a potent probiotic strain isolated from Koumiss in China. Genome Announc. 5:e0004817. doi: 10.1128 /genomeA.00048-17
Conflict of Interest Statement: The authors declare that the research was conducted in the absence of any commercial or financial relationships that could be construed as a potential conflict of interest.

Copyright (c) 2018 Yi, Luo and Lü. This is an open-access article distributed under the terms of the Creative Commons Attribution License (CC BY). The use, distribution or reproduction in other forums is permitted, provided the original author(s) and the copyright owner(s) are credited and that the original publication in this journal is cited, in accordance with accepted academic practice. No use, distribution or reproduction is permitted which does not comply with these terms. 